\title{
CORPORATE GOVERNANCE IN THE ROMANIAN RESEARCH-DEVELOPMENT ACTIVITY
}

\author{
Mircea-losif Rus \\ National Institute of Research and Development INCD URBAN INCERC, Cluj-Napoca, \\ Romania \\ mircearus2005@yahoo.com
}

\begin{abstract}
Corporate governance was implemented in companies managerial activity. It explicitly sets forth such companies organization way according to the principle of the separation of the executive management from the decisional one, especially in those companies which were heading towards bankruptcy. Thus, the two models of corporate governance appeared, the dual management system or the simple management system. The most implemented system in Romania is the dual one and this system is implemented both in the private system as well as in public entities. In the private system, the dual system is implemented both in companies listed on a regulated market as well as in those not listed. Timid steps are also taken by entities with research \& development (R\&D) activities, for the moment among those listed with the Bucharest Stock Exchange, but we need to mention here that some corporate governance principles are implemented also in companies which are not listed, as we will see in what follows. Maybe it will not be bad to have this management system implemented also in research-development national institutes as it would be easier to follow the way of how the public money is spent. At the same time, by its implementation, the corporate governance might have an important role also in what concerns the human resource of such institutes.
\end{abstract}

Keywords: corporate governance, research \& development, Stock Exchange, Financial Supervisory Authority, Romania

JEL classification: G23, G28, H11, H30

\section{Introduction}

Corporate governance represents an ensemble of the so called "rules of the game" by which companies are managed internally and supervised by the Board of Directors in order to protect the interests of all the participant parties. Thus, this governance has as its specific the rights and liabilities distribution between the various participants in a company such as the Board, the managers, the shareholders and other participant parties and which specifies the rules and procedures for decision making related to the business of the respective company (Aguilera and Jackson, 2010).

The necessity of this corporate governance appearance came up when many companies reached bankruptcy, the financial crises and, in particular, the gap between the compensations granted to the managers and the company performance of the last years, all these demonstrating that the introduction of the corporate governance was not just a means of the company survival but, rather a way to the corporation prosperity (OECD, 2015).

The need for corporate governance increased along time, as the distance increased between the owners of a business and those who manage it in their name. The appearance of several owners led to the appearance of the joint stock companies.

The need for corporate governance is brought forth by the sometimes divergent interests of the shareholders who wish to make sure that they will recover their investment in terms of 
maximum profitability taking into account the risk profile they accept and the managers appointed by them to run the entity who may have other objectives. Corporate governance wishes to align the interests of several parties so that the shareholders achieve their goals without generating frustrations among the managers (Păunescu, 2019).

\section{Corporate governance in a company with dual management system}

If in the case of small individual businesses where the owner is totally involved in the activity, the need for corporate governance is not imperative, in exchange, in the case of joint stock companies, where the stock owners are different from those who manage the company, an efficient system of corporate governance may make the difference between success and failure. The corporate governance rules applicable to Romanian companies may be found in Law no. 31/1990 and also in the additional legislation applicable to them. It may be the case of Law no. 24/2017 on the issuers of financial instruments and market operations, of the Law no. 297/2004 on the capital market, with the subsequent amendments and completions, or of the Government Emergency Ordinance no. 109/2011 on the corporate governance of public companies, with the subsequent amendments and completions. Mainly, joint stock companies are managed by a Board of Directors and a Supervisory Board, i.e. in a specific dual system (Păunescu, 2019).

Thus, the management of the joint stock company rests exclusively with the Board of Directors which fulfills the necessary and useful acts for the performance of its field of activity, except for those reserved by law to the responsibility of the Supervisory Board and to the general assembly of shareholders.

The members of the Board of Directors may not be also members of the Supervisory Board at the same time (Law no. 31/1990).

They may be revoked at any time by the Supervisory Board but, should the memorandum of association stipulate so, the members of the Board of Directors may also be revoked by the ordinary general assembly of the shareholders. In exchange, should the revocation of the members of the board be done without a just cause, then, they are entitled to the payment of damages.

The Board of Directors exercises its assignments under the control of the Supervisory Board. It is composed of one or several members, the number being usually odd. When there is one member, he bears the name of unique general manager. At the same time, in the case of joint stock companies whose annual financial statements make the object of a legal audit obligation, the Board of Directors is composed of at least three members (Dragomir, 2010). The Board of Directors represents the company in its relationship with thirds and in law related matters. If the memorandum of association does not stipulate it expressly, the members of the Board of Directors represent the company only by acting together and, in such a situation, subsequent to a unanimous vote, the members of the Board of Directors may mandate one of them to run certain operations or type of operations (Law no. 31/1990). Among the assignments of the Board of Directors is also the one which indicates that, once every three months, the board submits a report to the Supervisory Board on the company management, activity and possible evolution. Besides this information, the Board of Directors notifies the Supervisory Board any information related to the events which may have a significant influence on the company (Law no. 31/1990).

A very important thing is that the members of the Board of Directors submit to the Supervisory Board the annual financial statements and its annual report immediately after their draw up, together with a detailed proposal concerning the distribution of the profit resulted from the balance of the financial exercise, proposal which will also be backed up in the general assembly of the shareholders (Aguilera and Jackson, 2010). 
The members of the Supervisory Board are appointed by the general assembly of shareholders, except for the first members who are nominated by the memorandum of association. The candidates for the positions of member in the Supervisory Board are named by the existing members of the Board or by the shareholders (Dragomir, 2010).

The members of the Supervisory Board may be revoked at any time by the general assembly of shareholders with a majority of at least two thirds of the number of votes of the present shareholders. At the same time, the members of the Supervisory Board may not simultaneously be members of the Board of Directors and may not cumulate the position of member of the Supervisory Board with that of company employee (Dragomir, 2010).

The number of the Supervisory Board members is set up by the memorandum of association and that number cannot be inferior to 3 nor higher than 11 (Law no. 31/1990).

From its members the Supervisory Board elects the Chairman of the Board. Also, the Supervisory Board members cannot be at the same time members of the Board of Directors and they may not cumulate the position of Board member with that of company employee (Aguilera and Jackson, 2010).

In exceptional cases, when the company interest so requires, the Supervisory Board may convene the general assembly of shareholders (Dragomir, 2010).

There were many discussions on whether company management assignments may be transferred to the Supervisory Board. The answer is no, but, still, the company memorandum of association may specify that certain operations may not be performed but with the agreement of the Supervisory Board. The situation in which this Board does not express its agreement on that/these operation(s) then the Board of Directors may ask for the approval of the general assembly of shareholders (Law no. 31/1990). The resolution of the general assembly related to such an agreement is adopted with a majority of three fourths of the number of votes of the present shareholders. The memorandum of association may not set up another majority nor can it stipulate other terms for the agreement of the general assembly (Law no. 31/1990).

Another thing which rests with the Supervisory Board is its possibility to create advisory committees which are composed of at least two members of the Supervisory Board and assigned to run investigations and the elaboration of recommendations for the said Board in domains like audit, the remuneration of the members of the Board of Directors, of the supervisory board, of the personnel and the nominations of candidates for various management positions (Law no. 31/1990).

These committees must submit activity reports on their activity to the Supervisory Board (Păunescu, 2019).

\section{Corporate Governance at the Bucharest Stock Exchange}

The Bucharest Stock Exchange was re-established in 1995, after almost 50 years during which the market activity was suspended by the Communist regime and, since then, it witnessed a continuous development, being the most important Romanian stock exchange. The mission assumed by the BSE refers to the transformation of the local capital market in an active financing instrument of the Romanian economy (BVB, 2020).

The Bucharest Stock Exchange plays an important role in imposing the best principles of corporate governance. Thus, in 2015, it issued a new Corporate Governance Code applicable as of 2016 to all the companies listed on the regulated market. The Code replaces the one published in 2001 and revised in 2008 and puts to practice the experience accumulated along the years, intending to help the development of an attractive and competitive market at an international level on the basis of the best practices, transparence and trust (BVB, 2020). 
The Corporate Governance Code of the BSE is a set of practices and recommendations and puts to practice the principle "apply or explain". The principles recommended by the Code have as their aim the development of the trust granted by investors to the listed companies by the promotion of corporate governance improved standards in those companies (Law no. 24/2017, Law no. 297/2004).

The principles, which regard mainly the investors' access to information and the shareholders' rights protection, encouraging the companies to build up a strong relation with their shareholders and with other interested parties, are not compulsory but just recommended. Still, the companies admitted for trading on a regulated market have the obligation to include a corporate governance declaration in their annual report, in a distinct section, document which will include a self-assessment regarding the manner in which the recommended provisions were fulfilled, as well as the measures adopted with a view to the observance of the provisions which are not or just partially fulfilled (BVB, 2020).

Supplementary, in order to support the companies in their implementation of the Corporate Governance Code, the Stock Exchange published also a compendium of corporate governance good practices as well as a Manual on reporting in matters of corporate governance. Even if a company, other than those admitted for trading on a regulated market is not obliged to adopt the Corporate Governance Code issued by the Stock Exchange, the said Code, together with the supplementary materials issued by the Bucharest Stock Exchange may be used as a landmark of good practices in the relation with its investors (Law no. 24/2017, Law no. 297/2004).

\section{Corporate Governance for entities regulated by the Financial Supervisory Authority} In terms of corporate governance, certain companies must conform to supplementary requirements. Thus, the entities regulated by the FSA have the obligation to request the endorsement of the management structure members prior to the start of their mandate. Similar provisions may be also met in the case of the companies regulated by the National Bank of Romania (ASF, 2020).

The respective regulations apply to the following entities:

a) Companies of financial investments services;

b) Investments administration companies;

c) Collective investment bodies/alternative investment funds (FIA), set up by memorandum of association, managed internally;

d) Administrators of alternative investment funds (AFIA);

e) Central trustees;

f) Central counterparties;

g) Trading places administrators;

h) Insurance and/or reinsurance companies;

i) Administrators of privately administered pension funds, administrators of facultative pension funds and administrators of the occupational pension funds (ASF, 2020).

As an example, the Regulations of the Financial Supervisory Authority no. 2/2016 on the assessment and approval of the members of the management structures and of the persons who hold key positions within the entities regulated by the FSA stipulates that the regulated entities must make sure that the members of the management structures fulfill and maintain for the full duration of their activity development, requirements referring to:

- Knowledge, competences and professional experience;

- reputation, honesty and integrity,

- governance (ASF, 2020).

to that end, the regulated entities evaluate in advance the persons approved by the general assembly of shareholders as members of the management structures and request the 
endorsement of the FSA but have the obligation to set up adequate policies and procedures for the assessment of the initial and continuous adequacy of the assessed persons in order to make sure that they:

- have a good reputation,

- possess sufficient knowledge, competences and experience for the fulfillment of the position specific assignments,

- are capable of acting with honesty, integrity and have an independent thinking to evaluate and challenge in an argumentative manner the decisions of the executive management/higher management and any other decisions when necessary and to effectively supervise and monitor the decision making process,

- may allocate enough time, the case in which they hold several positions, for the fulfillment of the assignments afferent to the positions within the regulated entities and with the observance of the limitation of the number of management positions which can be held simultaneously.

The adequacy must be evaluate also individually, at the member level, but also collectively, at the level of the management structure (ASF, 2020).

\section{Corporate Governance in the research \& development activity in Romania}

The concept of corporate governance appeared and developed during the last century (XX), starting with the appearance of the conflicts of interests between the shareholders (owners) and managers. This appearance was a response to a series of spectacular failures from the private sector, in a relatively short time, failures which shocked by their ampleness and decreased the trust of the actors of the economic life in the financial statements of the entities, especially the investors' trust.

The corporate governance affects the manner in which the organizations function and their results, not directly, but by the actions and decisions made by the leaders. Just as Pérez paraphrases Edgard Morin, it can be said that the governance is somehow the "management of the management" (Pérez, 2003). This reference may explain a significant part of the enthusiasm, mixed with a little bit of mystery, caused by this concept in the field of the organizational science.

We may consider corporate governance as being a mosaic composed of several pieces interlaced between them which, together, bring value and importance within the entity. In the specialty literature from the area of the corporate governance and financial reporting, we may notice the fact that the published scientific surveys are oriented towards several research directions (towards the independence of the entity councils members, to audit and control, informational transparency, gain manipulation, introduction of the financial statements according to the Financial Reporting International Standards). These research directions will be introduced in the first chapter of the work (Kole and Lehn, 1999).

This concept is one of the complex concepts which stands at the border between several disciplines located in the economic sphere. The interdisciplinary aspect is noticed in the specialty literature by the fact that it is introduced in relation with various area of the economic environment like the audit, management, finances and accounting. This is seen as an ensemble of mechanisms which comes to the support of the management to order the decisions within the entity and reconcile the various interests appeared within the entity, mainly those between shareholders and managers.

The introduction and transparency of the information of an economic nature help cover the gaps with the information necessary to the investors, clients, employees, shareholders and may have a positive effect on the company revenues.

Corporate governance developed along the time due to the legal changes, to the new aspirations of the entities and of the interested parties, respectively, due the impact of the 
various external factors, having an important role in the harmonization of the financial statements and the economic stability which an entity needs after going through a period of financial decline (Mănoiu et al., 2015).

In Romania, the R\&D activity runs both public and private.

For public entities, corporate governance is exercised in accordance with the provisions of the Government Emergency Ordinance no. 90/2011 but, the mentioned ordinance expressly specifies which are the public entities that have to implement corporate governance, i.e.:

a) autonomous administrations;

b) national companies and entities, companies in which the state or an administrative-territorial unit is the sole, majority shareholder or in which holds control;

c) companies in which one or several public enterprises specified at letter a) and b) own a majority participation or a participation by which they hold control.

The R\&D activity is operated in public entities such as research-development national institutes, universities, institutes under the subordination of the Romanian Academy and in private companies usually organized as joint stock companies.

So, the R\&D institutes, the main "actors" on the R\&D activity market segment, both the ones under the coordination of the related ministry and the ones under the subordination of the same ministry are not included.

Even if they do not apply the corporate governance organization and principles, the public entities with $R \& D$ activity have an organization form close to the corporate governance: they have a Board of Administration and an Executive Board. The Board of Administration adopts the resolutions which are the most important for the respective entities and the said resolutions, by the General Manager, reach the Executive Board which starts the said resolutions implementation. At the same time, certain measures taken by the Executive Board have to reach the Board of Administration in order to be approved.

In exchange, the entities with R\&D activity which are organized as private joint stock companies and which are listed on a regulated market have to apply the corporate governance principles, as we said before. In what follows, I will introduce two examples of such companies of which one applies the corporate governance and the second does not apply such governance principles.

One example of private joint stock company is ICECON SA, a joint stock company which develops R\&D activities in the field of constructions. Though it should be organized under the incidence of the corporate governance, for the time being, the legislation does not oblige it to implement such governance.

It is worth mentioning the fact that the administrative organization of ICECON SA is similar to those who implemented corporate governance in the sense that, instead of having a Directorate and a Supervisory Board, here they have a Board of Administration and an Executive Board besides the Scientific Council composed of researchers, so still two management structures of which one executive and one administrative.

The Chairman of the Board of Administration is at the same time General Manager, a legal situation due to the fact that the said Chairman is also the majority shareholder of the respective company.

In exchange, CEPROCIM SA is a private company with R\&D activity listed with the Bucharest Stock Exchange (BVB) and bearing the symbol CEPO.

In terms of organization, CEPROCIM SA has a Board of Administration and an Executive Board which plays the supervisory role besides a Scientific Council composed of researchers.

In this case also, the Chairman of the Board is General Manager becoming ChairmanGeneral Manager but, like in the case of ICECON SA, this Chairman is also the majority shareholder and, if the corporate governance implemented by the Bucharest Stock Exchange does not ban that, this is very good. 
As it is listed on the Stock Exchange, CEPROCIM SA offers a greater transparency related to its activity as compared to the other entities of the R\&D activity as the financial results are public for all the shareholders and the activity of this company is subject to a greater number of rules as compared to other competitors on the same market.

At the same time, the negative financial results may lead to the decrease of the market value of a share as compared to the value of one share of a company with R\&D activity which is not listed and in which, usually, the majority shares package is owned by a small number or even by a single person.

Due to this fact, there are higher chances that CEPROCIM SA distributes dividends, a thing which is expected by the shareholders and leads to a more attractive value for this company as compared to other R\&D companies which do not distribute dividends and, on the contrary, it shows debts to various state budgets.

One good thing lately is that the financial statements of all the entities, including those with R\&D activity are public and may be seen especially by the business environment and thus, the said environment may have an image on its intentions related to investments in $R \& D$ activity.

\section{Conclusions}

We consider that it would be advisable that the corporate governance principles be implemented by all the entities of the R\&D activity (not so much in universities and those subordinated by the Romanian Academy) as there would be a total transparency related to the funds allocated from the state budget for the R\&D activity.

This could also lead to a higher capitalization of the fundamental research activity results which may easily turn into experimental research the situation in which the results of the fundamental research would have practical applicability and might enter in a production process and the resulted products would contribute, even if to a little extent, to the funding of the research-development activity (Rus, 2016).

Or, such funds resulted from the R\&D activity may contribute either to the development of a knowledge based society (Rus, 2013) or to the relaunch of the present economy, after the COVID-19 crisis, because the present economy, to a certain extent, led the economy to a situation similar to that generated by the economic crisis after 2008.

And last, but not least, the human resources existing in these R\&D institutes could be stimulated to stay in those entities and the young people who will come to this system would not be tempted to leave for the first offer coming from the private system.

In the research institutes subordinated by the Romanian Academy, many candidates for a doctor's degree were co-opted lately and they have high chances to stay in those institutes and be included in research teams after the acquirement of the doctor's titles, being stimulated to implement the results of the research they did during the doctorate studies.

And maybe then we could witness more inventions or innovations in the Romanian R\&D activity which could add to all those done so far of which we could mention the "artificial blood" or we could go to the Magurele Laser which, in time, may have applicability in medicine for instance, for the treatment of cancer in various body organs, for example.

And, last but not least, the set up of a capital fund by the Romanian state, of which rumors have spread years ago, could maybe stimulate more the research-development activity so that, along with the infrastructure development and the increase of the number of personnel in this field, the attracted funds would increase and that will implicitly go along with the implementation of a corporate governance in this field to a number of entities as great as possible. 


\section{References}

Aguilera, R.V., Jackson, G., 2010, Comparative and international corporate governance, Academy of Management Annals, 4(1), pp. 485-556, http://doi.org/10.1080/19416520.2010.495525

Dragomir, V.-D., 2010, Guvernanţă corporativă şi sustenabilitate în Uniunea Europeană, (Corporate Governance and sustainability in the European Union) Editura Economică

Law no. 3V1990 on trading companies, republished in the Official Gazette no. $1.066 / 17.11 .2004$, with the subsequent amendments and completions

Law no. $297 / 2004$ on the capital market published in the Official Gazette no. 571 of the 29th of July 2004 with the subsequent amendments and completions

Law no. 24/2017 on the issuers of financial instruments and operations on the market published in the Official Gazette no. 213 of the $29^{\text {th }}$ of March $2017 \mathrm{cu}$ with the subsequent amendments and completions

Government Emergency Ordinance no. 109/2011 on corporate governance in public enterprises published in the Official Gazette no. 883 of the $14^{\text {th }}$ of December 2011

Kole, S.R., Lehn, K., 1999, Deregulation and the adaptation of governance structure: the case of U.S. airline industry, Journal of Financial Economics, 52, pp. 89-117, https://doi.org/10.1016/S0304-405X(99)00005-7

Mănoiu, S. M., Damian, M. I. \& Strouhal J., 2015, Corporate governance in Romania. Case study regarding the application of the "Comply or Explain" Statement, International Journal of Entrepreneurial Knowledge, 3(2), pp. 40-58

Păunescu, M., 2019, Guvernanţa corporativă, managementul riscurilor şi controlul intern, Editura CECCAR (Corporate Governance, risk management and internal audit)

Pérez,R., 2003, La gouvernance de l'entreprise, Editure La Découverte

Rus, M.-I., 2013, The knowledge triangle in a knowledge-based society, Analele Universităţii Oradea. Ştiinţe Economice, XXII (1), pp. 942-947

Rus, M.-I., 2016, The Impact of financing the research and development activities worldwide. Comparative study, Discourse as a form of Multiculturalism in Literature and Comunication, pp. 187-192

ASF, 2020, http://asfromania.ro/legislaţie/legislaţie/5099-regulament-nr-2-2016-privindaplicarea-principiilor-de-guvernanta-corporativa-de-catre-entitatile-autorizatereglementate-si-supravegheate-de-asf [accessed on the 20th of June 2020]

BVB, 2020, http://bvb.ro/InvestorRelations/Overview [accessed on the 20th of June 2020]

OECD, 2015, G20/OECD Principles of Corporate Governance, OECD Publishing, http://dx.doi.org/10.1787/19789264236882-en

\section{Bio-notes}

Mircea-losif Rus is scientific researcher III at the National Institute of Research and Development INCD URBAN INCERC. Fields of interest: Finance, Accounting, Economic financial analys 